\title{
Ecoturism Potential and his Sustainable Development Oportunities in the Border Region between Slovakia and Poland
}

\author{
Čuka Peter $^{1}$, Osuch Wiktor ${ }^{1}$
}

\begin{abstract}
The aim of the paper is to identify the current state of ecotourism in Slovak - Polish borderlands. The research aims to identify the eco-tourism infrastructure, the motivation for using these facilities (by nationality) and economic behavior of tourists both on the Slovak and on the Polish side. The studied geographic zone is the area of the Western Carpathians in the Kysucká vysočina (Slovakia) and Beskyd Źywiecki districts in Poland. Ecotourism has tradition in Slovakia since the 1960s. Unlike the Polish countryside, in Slovakia many agricultural activities have disappeared or transformed in the given period. This allowed the development of cottage tourism and rural tourism, which in Slovak conditions is, besides agrotourism, the most prominent representative of ecotourism. Slovakia, alongside Scandinavia, France, Italy and the Czech Republic, is among the leading European countries with a high share of second homes. After 1990, agro-tourism has been dynamized in Slovakia and Poland. For the studied area we consider the centers of Čadca in Slovak and Źywiec on the Polish side - including their recreational background. In research were used methods of statistical analyzes of public data, field recognitioning, mystery shopping, but also qualitative methods for determining the tourist and economic behavior of ecotourism clients of the area under research. The study should highlight the real motives of eco-tourists' participation, the economic potential of ecotourism in the area and the main shortcomings that limit the future development of ecotourism.
\end{abstract}

Keywords: Ecoturism, Slovak - Polish border region, motives for eco turism, tourists eco behavior

\section{Introduction}

Ecotourism is a broad terminological, medotical and practical phenomenon. In Slovakia and Poland, the division of ecotourism into "agroturimus", "rural tourism" and application of "green tourism" as a tourist product are used in the hotel industry. [11] It is often associated with behavioralism called Corporate Social Responsibility. The beginnings of ecotourism, especially in Slovakia, reach in 60 years of 20 th century. At that time significant socio-economic changes have taken place. The advent of Communist power brought with it the joining of agricultural parcels and the creation of large-scale state and cooperative farms. Together with the rapid industrialization processes of Slovakia, these changes have led to the depopulation of rural communities and the strengthening of urbanization. Rural exodus has released a number of rural homes for recreational purposes.

In Poland, even during the socialist phase, the land of small farmers in private hands remained. This resulted in a high share of employment in the primary sector - in the Slovak Republic, in 1951 there was 40.68\% of workforce emploied in primary sector; in 
1970 it was only $23.54 \%$. [1, 3]

The development of the countryside and the conditions for the creation of ecotourism was therefore different in Poland and Slovakia.

However, the primary forms of ecotourism can be seen in both countries as rural tourism and, in particular, in Slovakia, widespread forms of cottage tourism.

\section{Work Objectives, Research Territories, Hypothes and Methodology}

The main objective of the work is to identify the forms of ecotourism development and their impact on sustainable development in the border areas of Kysucká Vysočina and Žyviecké Beskydy in the regions of Čadca and Źywiec.

The main methods include analysis of the perception of ecotourism products in the surveyed area in terms of their perceived quality, both on the supply side and on the demand side.

I. In the first part we have analyzed the forms of ecotourism in the given area. We tried to statistically analyze both statistical units at district level - NTS 4.

II. In the second part, through mystery shopping, we contacted public service and tourism services through the internet to find out:

- Offered ecotourism products

- Prices of Ecotourism products

- Quality of ecotourism products and quality of communication with the client.

III. In the third part, we were trying to verify the results of the second part (i.e. the offer of ecotourism products, their price and quality) with field surveys, mainly through interviews, surveys and observation, as well as the search for ecological products in tourism in the surveyed area and some consumer behavior (ecotourism tourism expenses).

Major research concerns include the identification of "objects of ecotourism". Official statistics databases do not register these objects separately, (Invalid hyperlink). So we had to make direct contact - by telephone or via the Internet - to find out which tourist infrastructure objects can be classified as "ecotourism".

On the Slovak territory, 46 tourist facilities were addressed, in Polish site it was 25 facilities. The number of respondents - tourists was on the Slovak side 264 and the Polish 222.

Qualitative research is also based on the following relevant resources [4] [5] [6] [7] [8].

\section{Results and Discussion}

\subsection{The Offer of Ecotourism in the Studied Area}

The offer of ecotourism in the studied area is heterogeneous. In Slovakia, the only travel agency "ecotourism products" is declared by NATRIX in Bratislava (www.natrix.sk). After addressing them with question of organizing ecotourism in Kysuce, we find out that they do not. A similar situation is also on the Polish side. Travel agencies do not offer a priori eco-tours to the examined area. Therefore, ecotourism in the border region of Kysucké Beskydy has an individual character.

We have also researched how many facilities offer real organic products on Polish and how much on the Slovak side.

Eco products of accommodation facilities in the studied area Slovakia and Polland are 
summarized in table 1 and table 2.

Table 1. Eco products of accommodation facilities in the studied area - Slovakia

\begin{tabular}{|l|c|c|c|c|c|c|}
\hline $\begin{array}{l}\text { Accommodation } \\
\text { type }\end{array}$ & $\begin{array}{c}\text { Small } \\
\text { domestic } \\
\text { animal } \\
\text { breeding }\end{array}$ & $\begin{array}{c}\text { Livestock } \\
\text { breeding }\end{array}$ & $\begin{array}{c}\text { Horse } \\
\text { breeding }\end{array}$ & $\begin{array}{c}\text { Supply of } \\
\text { domestic } \\
\text { food }\end{array}$ & $\begin{array}{c}\text { Supply of } \\
\text { domestic } \\
\text { eco-products }\end{array}$ & $\begin{array}{c}\text { Eco- } \\
\text { facilities }\end{array}$ \\
\hline Hotel & - & - & - & - & 2 & 3 \\
\hline Pension & - & - & 3 & 1 & 3 & 5 \\
\hline Camp & - & & & & & 1 \\
\hline Private & 1 & - & - & - & - & 4 \\
\hline Other & 1 & & 4 & 1 & 5 & - \\
\hline Total & & & & & & 13 \\
\hline
\end{tabular}

Source: own field research

Table 2. Eco products of accommodation facilities in the studied area - Poland

\begin{tabular}{|l|c|c|c|c|c|c|}
\hline $\begin{array}{l}\text { Accommodation } \\
\text { type }\end{array}$ & $\begin{array}{c}\text { Small } \\
\text { domestic } \\
\text { animal } \\
\text { breeding }\end{array}$ & $\begin{array}{c}\text { Livestock } \\
\text { breeding }\end{array}$ & $\begin{array}{c}\text { Horse } \\
\text { breeding }\end{array}$ & $\begin{array}{c}\text { Supply of } \\
\text { domestic } \\
\text { food }\end{array}$ & $\begin{array}{c}\text { Supply of } \\
\text { domestic } \\
\text { eco-products }\end{array}$ & $\begin{array}{c}\text { Eco- } \\
\text { facilities }\end{array}$ \\
\hline Hotel & - & - & - & 4 & 7 & 7 \\
\hline Pension & - & - & 5 & 5 & 6 & 12 \\
\hline Camp & & & & & & 1 \\
\hline Private & - & - & - & - & - & 3 \\
\hline Other & 4 & - & 1 & - & - & - \\
\hline Total & 4 & & 6 & 9 & 13 & 23 \\
\hline
\end{tabular}

Source: own field research

Research of Ecological products offer showed that there are "ecological facilities" in 13 Slovak (out of 46) and 23 Polish (out of 25) hotels, which include solar panels, energy management, own waste water treatment or other technological ecological facilities. Especially the breeding of horses is considered to be an organic product. There are 4 Slovak and 6 Polish resorts available.

Other organic products, such as agro-tourism farms, have not been confirmed in the studied area.

\subsection{Mystery Shopping Survey}

In the Mystery Shopping Survey, 11 facilities were contacted on the Slovak side, and 14 on Polish. It was a catering and accommodation facility in which we interviewed a series of questions through a controlled interview to find out what they have to offer, whether they are offering organic products, what is their cost. We also evaluated the quality of communication with the client (mystery shopper). We ranked the results in the rating scale from 1-5 (5 - excellent, 4 - good, 3 - sufficient, 2 - with shortcomings 1 inadequate). In Slovakia, we made interview in Slovak language and we use Polish in Poland, so we did not find the language competence of the workers in tourism. The results of mistery shopping are summarized in table 3. 
Table 3. Mystery shopping results

\begin{tabular}{|l|c|c|}
\hline & ČADCA & ŽYWIEC \\
\hline Number of offered eco-products catering & 2 & 3 \\
\hline Number of offered eco-products accomodation & 3 & 3 \\
\hline Number of accommodation ecological products offered & 3 & 4 \\
\hline Quality of communication with the client & 2 & 3 \\
\hline
\end{tabular}

Source: own field research

\subsection{Economic Activity of Tourists}

The economic activity of tourists is conditioned by their economic background and tourist markets. For comparison with our research, we have used fieldwork [10] activities in the Slovakia - Austria border region and the Polish - Slovak border region in the Eastern Tatras region [9].

Table 4. Comparison of expenditures of Slovak and Austrian tourists in the Slovak Republic and Austrian borders in 2013

\begin{tabular}{|l|c|c|c|}
\hline Bratislava region & $\begin{array}{c}\text { Turists from } \\
\text { Austria }\end{array}$ & $\begin{array}{c}\text { Turists from } \\
\text { Slovakia }\end{array}$ & $\begin{array}{c}\text { Others } \\
\text { turists }\end{array}$ \\
\hline What amount did you plan to spend in euro & 230 & 430 & 592 \\
\hline How much you really spent in euro & 233 & 369 & 308 \\
\hline Lower Austria region & & & \\
\hline What amount did you plan to spend in euro & 465 & 727 & 789 \\
\hline How much you really spent in euro & 414 & 559 & 767 \\
\hline
\end{tabular}

Source [10]

Table 5. Comparison of expenditures of Slovak and Polish tourists in the SR and PR surveyed territory of Eastern Tatras in 2017

\begin{tabular}{|l|c|c|}
\hline & $\begin{array}{c}\text { Slovak tourists - planned/ } \\
\text { real expenses in euro }\end{array}$ & $\begin{array}{c}\text { Polish tourists - planned/ } \\
\text { real expenses in euro }\end{array}$ \\
\hline Bukowina,Nowy Targ & $600 / 632$ & $380 / 420$ \\
\hline Ždiar, Matliare & $400 / 380$ & $500 / 485$ \\
\hline
\end{tabular}

Source: own field research

Table 6. Comparison of expenditures of Slovak and Polish tourists on ecotourism in border regions of the SR and PR surveyed territory in 2018

\begin{tabular}{|l|c|c|}
\hline & $\begin{array}{c}\text { Slovak tourists ecotourism } \\
\text { expediture planned/ real in euro }\end{array}$ & $\begin{array}{c}\text { Polish tourists ecotourism } \\
\text { expediture planned/ real in euro }\end{array}$ \\
\hline Źywiec & $230 / 250$ & $200 / 320$ \\
\hline Čadca & $300 / 360$ & $250 / 330$ \\
\hline
\end{tabular}

Source: own field research

In the field of economic behaviorality, we found that in Slovakia the planned expenditure of Slovak ecotourists in Slovakia was higher than expected by $20 \%$ - i.e. 360 EUR compared to the planned 300 EUR. The planned spending of Slovak ecotourists in Poland was higher by $8.7 \%$, namely 250 EUR compared to the planned 230 EUR. The planned spending of Polish eco-tourists in Slovakia was up 32\%, namely 330 EUR 
compared to the expected 250 EUR and their spending in Poland was 35\% higher, namely 32 EUR compared to the expected 200 EUR.

Overall, the highest spending was recorded by Slovak ecotourists on the Slovak side of 360 EUR and the lowest spending was declared by Slovak ecotourists on the Polish side of 250 EUR. In comparative studies, we recorded the largest spending of 767 EUR in tourists in the Lower Austria region (still in 2013). Determinant of economic behaviorality is also the offer of services, the price of services and the number of overnights during the stay.

\section{Final Evaluation - Conclusion}

The main research results are as follows:

- In the cross-border zone of the Polish-Slovak border in the Zywiec Beskydy and Kysucká Vrchovina regions, ecological forms of tourism are heterogeneous, as confirmed by other studies in Polish or Slovak territory [12,13]

- In Slovakia, ecotourism is dominated by forms of second homes (cottages), in the territory of Čadca there are 245 cottages and second homes, which is the average of 3.2 statistical households. On the Polish side this indicator is almost two times lower - only 7.2. - In the district of $\check{C}$ adca, we investigated 13 ecotourism facilities, in the Žywiec district it was 23

- Mystery shopping has confirmed from medium to low level of services offered, as well as client communication in the given area is rather average

- The price sessions of the territory and the offer of tourist services are lower compared to the comparative territories of Lower Austria and the Tatras.

- Slovak tourists declared economic activity in Lower Austria at the level of 308 EUR, Slovak Tatras 380 EUR, in the Polish Tatras 680 EUR, and in our surveyed area it was 360 EUR in Slovak and 250 EUR on the Polish side

- Polish tourists declared economic activity in Slovak Tatras 485 EUR, in the Polish Tatras 420 EUR, and in our investigated area 330 EUR on Slovak side and 330 EUR on the Polish side.

- Finally we identified ecocentrums on the Polish and Slovak side

Table 7. Eco tourism centres in research area - Źywiec

\begin{tabular}{|c|c|c|c|c|c|c|}
\hline $\begin{array}{l}\text { Accommodation } \\
\text { type }\end{array}$ & \begin{tabular}{|l|} 
Small domestic \\
animal \\
breeding
\end{tabular} & $\begin{array}{l}\text { Livestock } \\
\text { breeding }\end{array}$ & $\begin{array}{l}\text { Horse } \\
\text { breeding }\end{array}$ & $\begin{array}{l}\begin{array}{l}\text { Supply of } \\
\text { domestic } \\
\text { food }\end{array} \\
\end{array}$ & \begin{tabular}{|l} 
Supply of \\
domestic eco- \\
products
\end{tabular} & Eco-facilities \\
\hline Hotel & - & & - & - & $\begin{array}{l}\text { Radziechowy } \\
\text { Źywiec, } \\
\text { Zwardoń }\end{array}$ & $\begin{array}{l}\text { Źywiec, Rychwald, } \\
\text { Korbielów }\end{array}$ \\
\hline Pension & & & $\begin{array}{l}\text { Źywiec, } \\
\text { Rychwald, } \\
\text { Milówka } \\
\end{array}$ & Zwardoń & $\begin{array}{l}\text { Zwardoń, Milówk } \\
\text { Lipowa, Jeleśnia }\end{array}$ & $\begin{array}{l}\text { Źywiec, Zwardoń, } \\
\text { Wegierska Górka, } \\
\text { Przybedza, Ciecina }\end{array}$ \\
\hline Camp & & & & & & Źywiec \\
\hline Private & - & & - & - & - & $\begin{array}{l}\text { Źywiec, Wegierska } \\
\text { Górka, Rychwald, } \\
\text { Milówka }\end{array}$ \\
\hline Other & Rychwald & - & Źywiec & $5^{-}$ & - & - \\
\hline Total & 1 & & 4 & 1 & 5 & 13 \\
\hline
\end{tabular}

Source: own field research 
Table 8. Eco tourism centres in research area - Čadca

\begin{tabular}{|c|c|c|c|c|c|c|}
\hline $\begin{array}{l}\text { Accommodation } \\
\text { type }\end{array}$ & $\begin{array}{l}\text { Small } \\
\text { domestic } \\
\text { animal } \\
\text { breeding }\end{array}$ & \begin{tabular}{|l|} 
Livestock \\
breeding
\end{tabular} & \begin{tabular}{|l} 
Horse \\
breeding
\end{tabular} & $\begin{array}{l}\text { Supply of } \\
\text { domestic food }\end{array}$ & $\begin{array}{l}\text { Supply of domestic } \\
\text { eco-products }\end{array}$ & Eco-facilities \\
\hline Hotel & & - & - & \begin{tabular}{|l|} 
Čadca, \\
Svrčinovec,Makov, \\
Nová Bystrica
\end{tabular} & $\begin{array}{l}\text { Čadca, Svrčinovec, } \\
\text { Dlhá,Vysoká, } \\
\text { Turzovka,Olešná, } \\
\text { Nová Bystrica }\end{array}$ & $\begin{array}{l}\text { Čadca,Svrčinovec, } \\
\text { Makov,Klokočov, } \\
\text { Krásno, Dlhá, Vysoká, }\end{array}$ \\
\hline Pension & & & $\begin{array}{l}\text { Čadca, } \\
\text { Svrčinovec, } \\
\text { Krásna, } \\
\text { Raková, } \\
\text { Makov }\end{array}$ & \begin{tabular}{|l} 
Dlhá,Vysoká, \\
Turzovka,Olešná, \\
Nová Bystrica
\end{tabular} & $\begin{array}{l}\text { Čadca, Svrčinovec } \\
\text { Makov,Skalité } \\
\text { Scrčinovec,Krásno }\end{array}$ & \begin{tabular}{|l|} 
Čadca,Svrčinovec, \\
Makov,Klokočov, \\
Krásno, Dlhá, Vysoká, \\
Klokočov,Korňa, \\
Turzovka,Olešná, \\
Nová Bystrica \\
\end{tabular} \\
\hline Camp & & & & & & Makov \\
\hline Private & & - & - & - & & $\begin{array}{l}\text { Čadca, } \\
\text { Makov,Klokočov }\end{array}$ \\
\hline Other & $\begin{array}{l}\text { Makov, } \\
\text { Krásna, } \\
\text { Vysoká, } \\
\text { Stará } \\
\text { Bystrica }\end{array}$ & & Raková & & & \\
\hline Total & 4 & & 6 & 9 & 13 & 23 \\
\hline
\end{tabular}

Source: own field research

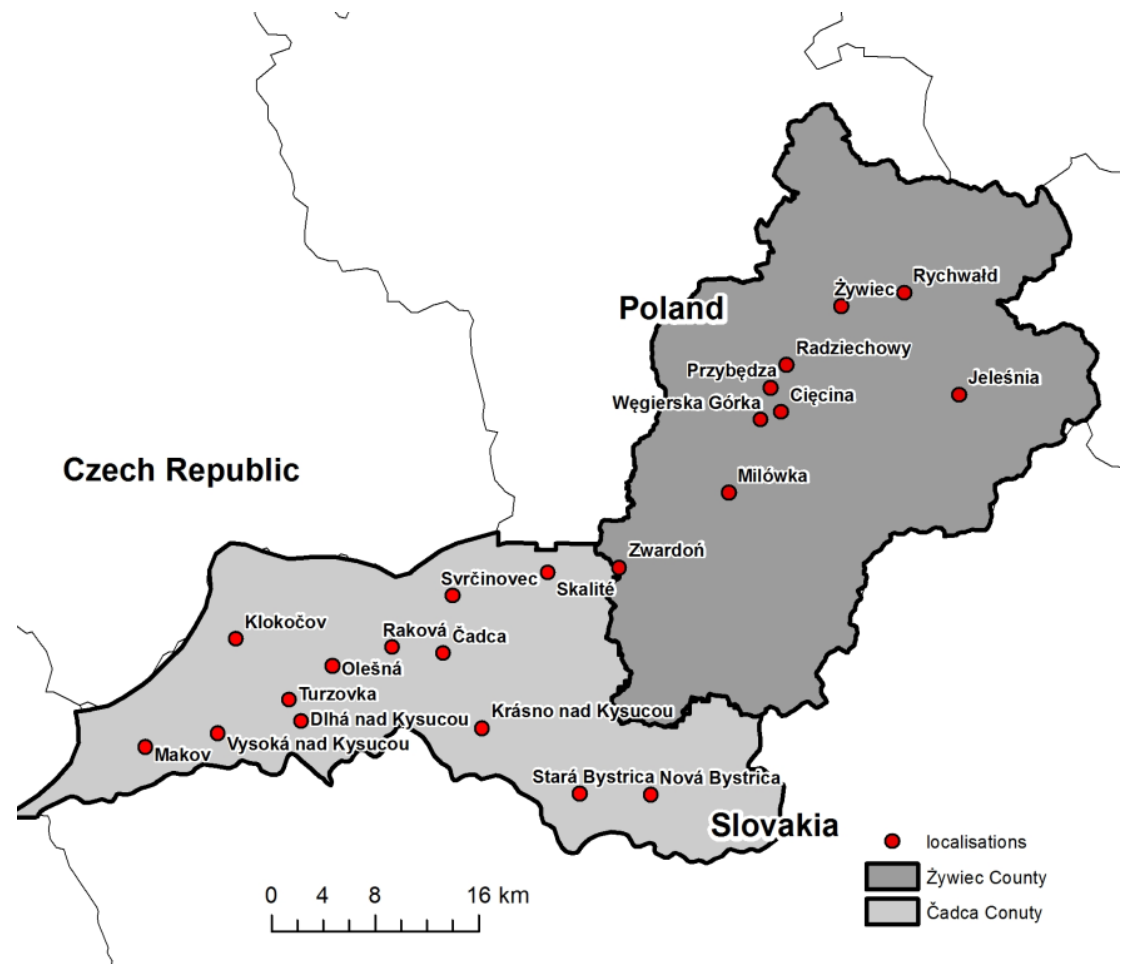

Fig. 1. Map of eco turism centres in field research

Source: own field research 


\section{References}

História. (2017) Revue o dejinách a spoločnosti,5/2017 Bratislava s.22-34 ISSN 1335-8316

www.statistics.sk

Klimczyk, P. (2008) Analiza zatrudnienia w gospodarce Polskiej na tle innych Państv Unii Europejskiej. In. Zeszyty Naukowe Uniwerstytetu Ekonomicznego w Karkowie Nr. 793, 2008 ISSN 1898 - 6447

Straaten,J,V.d. (1997) The Economic Pitfalls and barriers of the Sustaible Turism Concept in the Case of National Parks. In. NATO ASI Series, Vol 40 Springer, Berlin - Heidelberg 91.127.14.173

Angrosino, M. (2010) Badania etnograficzne i obserwacyjne. PWN Warszawa s.186 ISBN 978-83-01-16292-4

Denzin, K. N., Lincoln,Y.S. (2009) Metody badań jakościowych. PWN, Warszawa tom 2 s. 725 ISBN 978 - 83 $-01-15879-8$

Butler, R. W. (1980) The concept of a tourist area cykle of evolution, implications for managment of resources. In: The Canadian Geographer Nr. 24/1 s. 312

Theodore, M. K. Theodore, L. (2010) Environmental management. CRS Press. Taylor Francis group, s.556, ISBN 13-978-1-4200-8907-3

Cuka, P. (2017) Strategies for the development of tourism in Slovakia in the last two decades. In. Conference Enterpreneuship - Education. Condition for developmnet of Entrepreneurship. Conference lecture

Destinatour (2014) Dotazníkový prieskum a návrh tvorby produktov cestovného ruchu v cezhraničnom priestore Bratislavského kraja a Dolného Rakúska. Bratislavský samosprávny kraj, Niederösterreich-Werbung GmbH., Dolné Rakúsko. Turizmus regiónu Bratislava. (http://www.region-bsk.sk/clanok/o-projekte-uber-das-projekt-758370.asp)

Zaręba,D. (2010) Ekoturystyka. PWN Warszawa, 181 ISBN 978 - 83-01-16017-3

Labaja,M.(2009) Zrównowažona turystyka na obsz̧arze Podbabiogórza. Studia i Monografie, WSTiE w Suchej Podbeskidzkiej s.170

Huttmanová, E. (2016) Sustainable Development and Sustainability Management in the EU Countries. In. European Journal of Sustainable Dvelopment. Vol. 5 No 4. European Center of Sustainable Development s. $475-483$ ISSN 2239-5938.

\section{Internet}

www.stat.gov.pl

www.statistics.sk

www. eurostat.eu

www.natrix.sk 